\title{
Obituary: Howard Taylor
}

The Editorial Board of MCR recently lost one of its longest-serving members, Dr Howard Taylor, who died peacefully early in November 2016.

Howard was born near Manchester in April 1940. He was educated at school in Somerset and at university in Manchester. He began his professional career with consultants Sir Alexander Gibb, working both in design and on site before joining the Cement and Concrete Association in 1964-where he was to spend some 14 years concerned with research, design development and professional education. Among the topics on which he made particular contributions were shear, detailing and precast construction. Included in his more than 60 publications were titles such as Investigation of the Forces Carried Across Cracks in Reinforced Concrete Beams and Shear strength of large beams-topics that are still pertinent today; thereby, confirming Howard's often stated view that today's researchers would benefit from studying the historical development of their subject.

In 1978 Howard's career changed direction somewhat when he moved to become Chief Engineer of Dow Mac, remaining there during the subsequent changes to Costain Building Products and Tarmac Concrete, where he became the Technical Director.

Howard readily gave time to professional activities in the field of structural concrete, including many years spent chairing the judging panel for the Concrete Centre's Design competition; more broadly he was actively involved with the Institution of Structural Engineers, including serving as their President from 1993 to 1994. His technical eminence was recognised when he was elected to the Royal Academy of Engineering in 1993. For over 40 years he assisted the work of BSI, contributing to work on CP110, BS8110, BS5400 and Eurocode 2. At various times he chaired the BSI's committees on Concrete Bridges and Structural Design Codes. For several years he acted as a Visiting Professor in the Principles of Design to the Engineering Faculty at the University of Nottingham.

Throughout his career Howard brought calm good sense, respect for others and the utmost professional integrity to all he did. We will all miss him.

Robert Vollum and David Nethercot

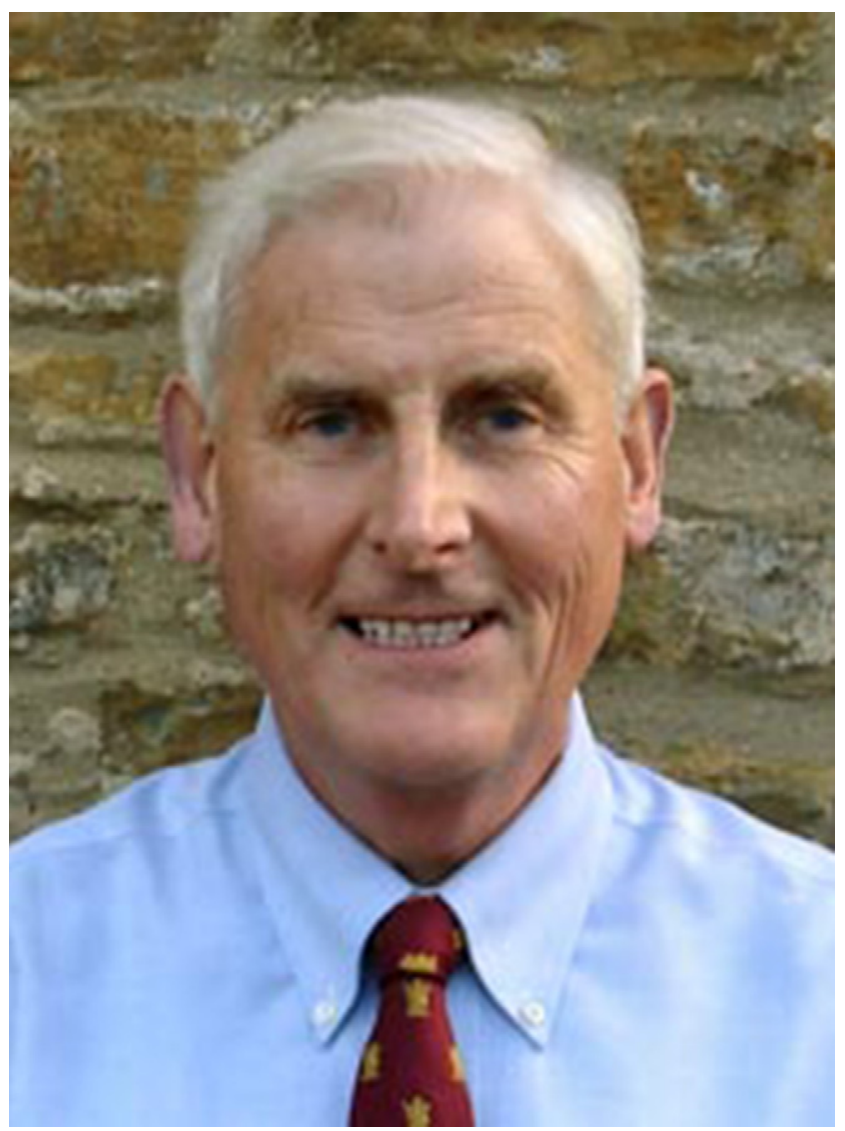

Howard Taylor, 1940-2016 